DOI 10.37882/2223-2982.2020.12.30

\title{
ЧЕЛОВЕК И ВРЕМЯ В ИСТОРИИ (К ВОПРОСУ $О$ ФОРМИРОВАНИИ ОБЩЕСТВЕННОГО СОЗНАНИЯ В 1930-Е ГОДЫ)
}

\section{PERSON AND TIME IN HISTORI (ON THE FORMATION OF PUBLIC CONSCIOUSNESS IN THE 1930S)}

N. Pepelina

Summary: The article attempts to analyze the process of formation of the public historical consciousness of the Soviet people using the example of the development of historical education in the 1930s, attracting a diverse historiographic base to the solution of this problem.

Keywords: public historical consciousness, historical perspective, person, history textbook, historical source, archival materials, mentality.

\author{
Пепелина Наталья Игоревна \\ К.и.н., дочент, ФГБОУ ВО «Московская государственная \\ академия ветеринарной медицины \\ и биотехнологии - МВА им. К.И. Скрябина» \\ referatpep@yandex.ru
}

Аннотация: В статье предпринята попытка на примере развития исторического образования в 1930-е годы проанализировать процесс формирования общественного исторического сознания и ментальности советского человека, привлекая к решению указанной задачи разнообразную историографическую базу.

Ключевые слова: общественное историческое сознание, историческая перспектива, человек, ментальность, учебник истории, исторический источник, архивные материалы.
$M$ ы традиционно рассматриваем науку как особый вид деятельности, направленный на приобретение нового знания и обладающий рядом характерных черт, таких как рациональность, системность, доказательность, объективность. Конечная цель любого исследования - достижение истины, то есть адекватного отражения реальности. История как область научного знания не является исключением. Изучение прошлого, его объективный анализ, умение понимать смысл произошедших событий есть обязательное и необходимое условие для всестороннего развития личности. Знакомясь с комплексом представлений об особенностях общественного развития, причинах и последствиях крупных событий национального и мирового значения, понимаем историю как обобщенный опыт прошлого и как способ самопознания народа.

Одна из ключевых проблем исторического познания - это принадлежность его объекта к уже случившемуся «и существование его для историка в основном не в качестве реального бытия, а в виде его остатков письменных, устных и вещественных» [8, с. 29] - того, что называют историческими источниками. «Механизм познания истории таков, что он осуществляется не безотносительно к позициям субъекта в условиях современной ему социальной среды, не в обход их, а через эти позиции, на их основе» [8, с. 30]. Эта специфическая черта истории требует определенного подхода к изучению прошлого и его научной реконструкции. Историческая антропология предлагает «взглянуть на происходящие процессы с позиций их участников» [9, с. 263]. Один из основателей французской школы «Анналов» Л. Февр пи- сал: «история - наука о Человеке; она использует факты, но это факты о человеческой жизни. Задача историка: постараться понять людей, бывших свидетелями тех или иных фактов... История, разумеется, использует тексты, но это человеческие тексты... И у каждого из этих слов своя история» $[10$, с. 19].

В 1920-1930-е годы в СССР проходил сложный и неоднозначный процесс формирования исторического сознания советских граждан на основании новых условий жизни, новых идеологических установок. Понимание особенностей общественного сознания в указанный период - важная составляющая в вопросе создания наиболее полной картины прошлого.

Быстрые смены исторических концепций и подходов в результате революционных событий и последующих за ними лет не могли не отразиться на специфике понимания советскими гражданами происходящего. Исторический процесс, отразившийся в их сознании, включал в себя совершенно различные концепции, положения и подходы, что, в числе прочего, сказалось на общем низком уровне научной и политической грамотности в области исторического знания. В неспокойной внутренней и внешней политической обстановке актуальной задачей было сформировать обоснованную единообразную систему исторических знаний, которая поддерживала бы государственный курс и являлась составляющей частью идеологической концепции, при этом соответствовала научным исследованиям отечественной истории. Именно для достижения подобных целей было принято решение о создании новых школьных учебников по от- 
ечественной истории. Советское правительство во главе со Сталиным приложило в первой половине 1930-х годов значительные усилия для того, чтобы добиться от историков желаемого результата. После ряда неудач в 1936 году был объявлен конкурс на лучший исторический учебник для начальной школы. На страницах центральных органов печати появились правительственные документы, заключавшие в себе требования к учебнику. Они состояли в трех главных положениях: политическая выдержанность, научность, методическая грамотность. В 1930-е годы продолжались исследования по многим темам, не изучавшимся ранее, но которые должны были найти отражение в учебнике [6, с.1]. Наиболее новые разработки нужно было донести до населения в доступной для него форме с помощью учебника по истории.

Bсе граждане могли присылать свои рукописи на конкурс, поэтому среди участников оказались не только ученые-историки, но и люди, не обладавшие необходимыми знаниями в области истории. Это работники культуры, печати и образования, а также пропагандисты, обществоведы, рабочие и колхозники, учителя истории (в большинстве своем из провинции, при этом их конкурсные рукописи выявляют чрезмерно низкий уровень знаний учителей), и просто те, кто увлекался историей, но чьи исторические знания оказались минимальны. Они были некомпетентны в вопросах истории, содержании учебного материала, политических нюансах. И учащимся, соответственно, могли предложить лишь свои бытовые воззрения на исторические процессы, что, понятно, не шло на пользу школьникам.

Бессистемность представлений усугубилась использованием участниками конкурса разных, зачастую взаимоисключающих источников информации. Во-первых, работы дореволюционных историков - запрещенные и отвергнутые в 1920-е годы, и возвращенные в 1930-е годы. Несмотря на то, что правительство озвучило предложение обратиться к опыту «буржуазных» ученых, необходима была адаптация текста этих учебников с позиций марксисткой методологии и соответствующей политической критики. Но обыватели не смогли, а скорее всего и не осознали, не поняли этого требования, и многие механически вернулись к изложению предмета, принятому до революции. Во-вторых, книга М.Н. Покровского «Русская история в самом сжатом очерке» и учебники по зарубежной истории. Несмотря на критику, вероятно, малопонятную большинству населения, эти работы продолжали использовать в качестве источников информации. В-третьих, научно-популярная и агитационно-политическая литература, выполнявшая воспитательную функцию и направленная на борьбу с буржуазной идеологией [2]. В-четвертых, требования правительства и сопровождавшие их статьи, появившиеся в преддверии конкурса на лучший учебник в газетах, следовательно, ставшие известными населению.
Большинство представленных рукописей этой группы использовали перечисленные выше источники, поэтому можно выделить общие черты, характерные для них. Конкурсанты в основном механически переписывали материал, который они посчитали наиболее подходящим, с доступных им работ, по сути, повторяя близко к тексту все концептуальные рассуждения авторов, излагали содержание упрощенным языком, то есть так, как, видимо, понимали его сами авторы рукописей. Механически стараясь видоизменить текст в соответствии с условиями правительства, авторы сохраняли методологические и концептуальные особенности источников. Повторяя содержание книг М.Н. Покровского или буржуазных историков, они вплетали в свое изложение, как правило, искусственно требуемые властью оценки событий и исторических личностей. В частности, установку показать связь истории с современностью авторы понимали буквально - к историческим событиям далекого прошлого они применяли современные утверждения и выражения. Конкурсанты дополняли рукописи собственными умозаключениями, основанными на бытовых представлениях, которым свойственен определенный традиционализм. В механическом переписывании, добавлении требующихся оценок, «упрощении» и «украшении» языка текста, проскальзывает личное отношение участников конкурса к излагаемому материалу.

Анализ архивных материалов, в которых представлены работы, присланные на конкурс, позволяет сделать вывод об упрощенном восприятии исторических проблем простыми людьми, основанном на сведениях, полученных из разных, часто неоднозначных или неподходящих, источников. Весь приобретенный материал пропускался через призму бытового видения исторических проблем [7, с. 254]. Можно предположить, что рассуждения об исторических событиях, изложенных в присланных рукописях, были свойственны большей части населения. В подобных «учебниках» отразилось отношение простых граждан к историческому процессу, тот синтез идей и концепций, которые менялись с калейдоскопической скоростью в течение двух десятилетий Советской власти. В результате у огромной массы малообразованного населения к середине 1930-х годов сложились весьма разрозненные, противоречивые знания об историческом процессе в целом и всех его составляющих в частности. Очевидно, что требовалась стройная единообразная система исторических взглядов, поддерживающая государственный курс и являющаяся составляющей частью идеологической концепции, отраженной в учебнике отечественной истории для школы. Он должен был содержать не только политические установки партии, направленные на формирование ментальности советского человека, но и соответствовать последним достижениям науки в области изучения истории.

В основе вышесказанного лежат изучение и анализ 
разнообразных исторических источников, которые систематизированы и объединены в группы. Одна из таких групп включает в себя нормативно-законодательные акты, состоящие из правительственных постановлений. Это руководящие документы, отражающие суть преобразований в школьном историческом образовании. Именно они определили направление концептуальных положений новой советской идеологической системы, занявшей во второй половине 1930-х годов ключевую позицию в исторической науке и историческом образовании.

Документами делопроизводства представлена еще одна группа источников. Она весьма широка и разнообразна. Включает в себя различные распоряжения, приказы Народного комиссариата просвещения, школьные программы и учебные планы, проекты постановлений Коллегии НКП (Материалы НКП хранятся в Государственном архиве Российской Федерации (ГАРФ), фонд 2306). Наркомпрос РСФСР проводил масштабную работу по трансформации исторического образования в школе в 1920-х и 1930-х годах. В 1920-е годы была создана единая трудовая школа, изменившая подходы к преподаванию в соответствии с новыми идеологическими веяниями. В этот же период значительные изменения затронули общественно-историческое образование, складывалась комплексная система обучения, что привело к иному подходу в планировании работы в общеобразовательной школе. Исследование перечисленных материалов приводит к пониманию специфики нововведений в сфере советского школьного исторического образования в указанные период. В 1930-е годы документальная база НКП хранит данные о ходе работ по созданию учебников по истории. Комиссариатом просвещения были проведены совещания с учеными-историками, с учителями средних школ; создавались многочисленные комиссии по истории

Руководящая роль советского правительства в работе над школьными историческими учебниками и, как следствие, над новой идеологической концепцией, нашла отражение в большом массиве архивных материалов. Здесь встречаем проекты постановлений, процесс их создания и трансформаций, протоколы заседаний Комиссии ЦК ВКП(б) по написанию учебников истории.

Значительную роль в постижении процессов формирования общественного сознания 1920-1930-х гг. играют хранящиеся в архивах рукописи учебников, присланных на конкурс на лучший учебник по истории СССР для начальной школы, письма историков, принимавших участие в этой работе, а также рецензии, замечания членов жюри конкурса, советских ученых-историков, преподавателей истории, работников исторической науки СССР. Эти документы позволяют реконструировать особенности работы над учебниками по отечественной истории, осмыслить специфику видения населением исторического процесса, проследить трансформации научных взглядов историков.

Анализируя источниковую базу изучаемого вопроса, необходимо сказать о публицистике. Ключевую позицию среди исторической литературы в 1920-е годы занимала книга М.Н. Покровского «Русская история в самом сжатом очерке» [5]. «Красный профессор», организатор советской исторической науки, Покровский фактически переписал русскую историю, переложив ее на марксистскую теорию развития капитала. На протяжении более чем десятилетия эта работа являлась для советских граждан главным источником исторических знаний по отечественной истории. Кроме того, в 1920-е годы были написаны (также основываясь на подходе Покровского) учебники по зарубежной истории. Чрезвычайно интересны для исследователя макеты учебников по истории СССР, подготовленные в 1934-1936 годах советскими историками по заданию правительства, но подвергшиеся его жесткой критике. И, конечно, учебники по истории СССР, в первую очередь, учебник А.В. Шестакова для начальной школы, выпущенный в 1937 году [11].

Статьи историков, педагогов, методистов встречаются на страницах многочисленных периодических изданий. Их содержание представляет собой отражение и понимание правительственных документов, касающихся вопросов исторического образования советских граждан (Материалы публиковались в центральных и специальных газетах («Правда», «Известия», «За коммунистическое просвещение» и др.) и в крупных партийных и исторических журналах («Большевик», «Историкмарксист», «История в средней школе» и др.)).

Исследуя исторические источники в их многообразии, ученый приходит воссозданию картины прошлого в центре которой - человек с присущими ему ментальными чертами и особенностями восприятия соответствующего его времени исторического момента. На формирование этих черт оказывала влияние целая совокупность факторов, отражающих историческое сознание общества, которое состоит из трех важных компонентов: официальная концепция истории; профессиональная наука; историческая память различных слоев населения [1, с. 193]. Все эти источники дают инструменты для понимания человека своей эпохи, позволяют познавать историческую и культурную реальность через ее восприятие личностью.

Изучение исторического сознания советского общества создает возможность сделать ряд важных выводов, которые могут помочь в объяснении многих важных сторон жизни страны и человека в 1920-1930-е годы и проанализировать последующие перемены, произошедшие в Росси [1, с. 208]. 


\section{ЛИТЕРАТУРА}

1. Алексеева Г.Д. Историческая наука в России. Идеология. Политика. (60-80-е годы ХХ века) - М., 2003. - 248 с.

2. Алексеева Г.Д. Октябрьская революция и историческая наука 1917-1923 годы. - М., 1968. - 217 с.

3. Дубровский А.М. Историк и власть. - Брянск, 2005. - 424 с.

4. Пепелина Н.И. Эволюционные процессы в советском школьном историческом образовании. Диссертация на соискание ученой степени кандидата исторических наук. - М., 2011. -216 с.

5. Покровский М.Н. Русская история в самом сжатом очерке. - М., 1933. - 473 с.

6. Постановление СНК СССР и ЦК ВКП(б) «0б организации конкурса на лучший учебник для начальной школы по элементарному курсу истории СССР С краткими сведениями по всеобщей истории» // Правда. 4.03.1936. - с. 1

7. РГАСПИ. Ф. 17. ОП. 120. Д. 363. Л. 254

8. Смоленский Н.И. Теория и методология истории. - М., 2008. - 272 с.

9. Теория и методология истории. - М., 2014. - 504 с.

10. Февр Л. Бои за историю. - М., 1991. - 633 с.

11. Шестаков А.В. Как преподавать историю СССР по новому учебнику// Исторический журнал. - 1937. - № 8. С. 5

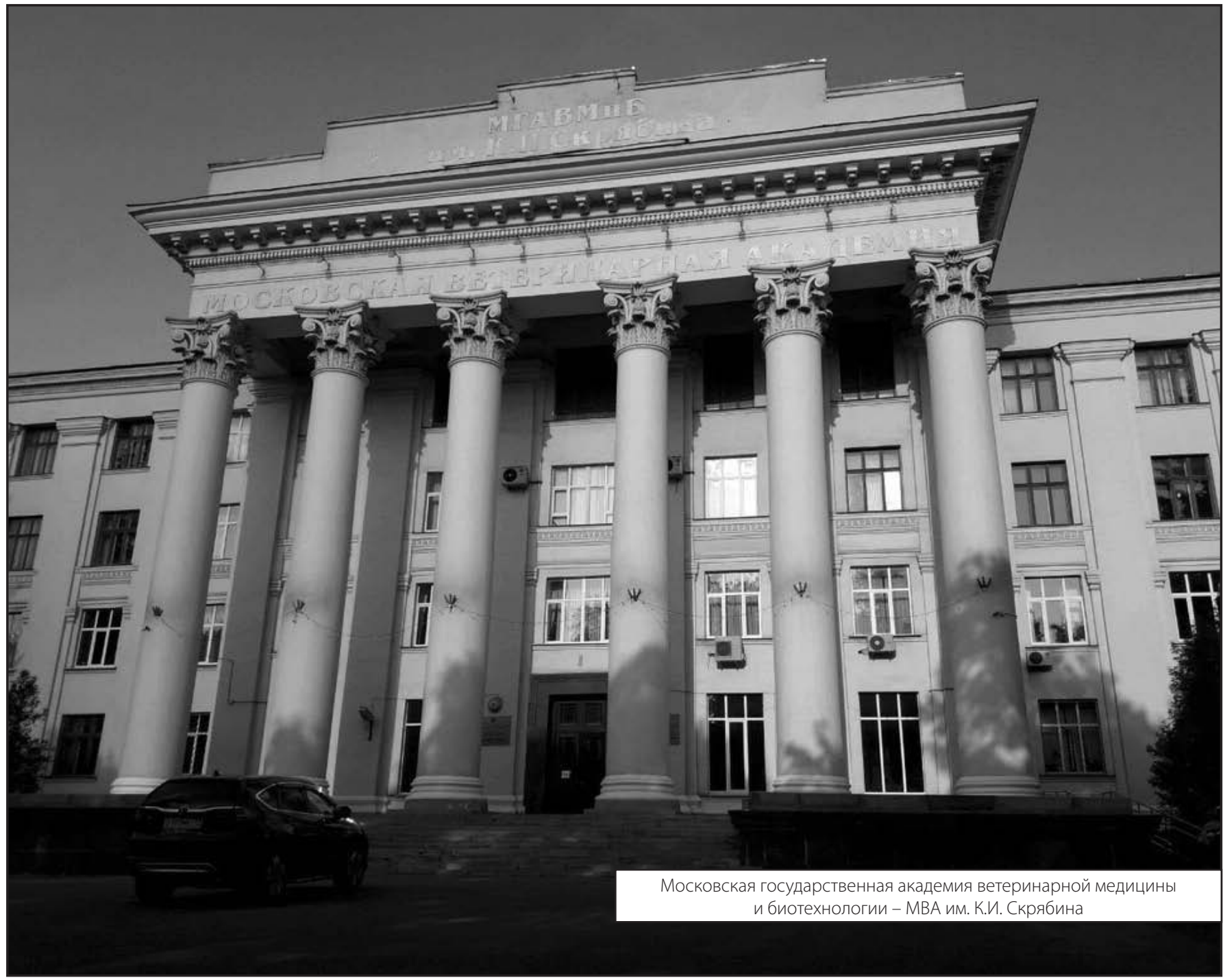

